\title{
Physical, chemical and sensory properties of sour grape based beverages and monitoring of their quality changes during storage
}

\section{Ali Güler}

\author{
Viticulture Research Institute, Manisa, Turkey
}

\section{Keywords:}

Antioxidant

Beverage

Polyphenols

Sour grape

juice

Storage

\begin{tabular}{l} 
Article history: \\
Received \\
24.03 .2021 \\
Received in \\
revised form \\
10.08 .2021 \\
Accepted \\
30.09 .2021 \\
\hline
\end{tabular}

\section{Corresponding} author:

Ali Güler

E-mail:

aligguler@

gmail.com

DOI:

$10.24263 / 2304-$

974X-2021-10-

$3-4$

\section{Abstract}

Introduction. The aim of the research is to determine the usability of the sour grape concentrate in beverages and monitoring of their quality changes under different storage conditions.

Materials and methods. Sultani Çekirdeksiz ( $V$. vinifera L.) sour grapes were used as material to obtain the concentrate. Total phenolic contents were determined according to Folin-Ciocalteu methods. Antioxidant properties of the samples were analysed with FRAP, CUPRAC, ABTS and DPPH methods. Contents of sugars and individual phenolic compounds were determined by HPLC, and contents of minerals were determined by Atomic Absorption Spectroscopy methods.

Results and discussion. Total phenolic content, antioxidant capacity, individual phenolic compounds and mineral amounts increased depending on used sour grape concentrate rising ratios in manufactured carbonated drinks (CD), sherbet (SH) and iced tea (IT) samples. Total phenolic contents were ranged from 32.7 to $40.82 \mathrm{mg} / \mathrm{L}$ in $\mathrm{CD}$, from 27.3 to $35.0 \mathrm{mg} / \mathrm{L}$ in SH and from 357.08 to $365.64 \mathrm{mg} / \mathrm{L}$ in IT samples. Antioxidant capacity values were between 66 and 4319 $\mu \mathrm{M}$ TE/L for ABTS method, 214 and $4893 \mu \mathrm{M}$ TE/L for CUPRAC and between 186 and $4319 \mu \mathrm{M}$ TE/L for FRAP methods. IT samples had more antioxidant capacity than $\mathrm{SH}$ and $\mathrm{CD}$ samples.

The most abundant minerals in the beverages were Na (77.41$692.28 \mu \mathrm{g} / \mathrm{mL}), \mathrm{Ca}(159.03-358.25 \mu \mathrm{g} / \mathrm{mL})$ and Fe $(8.74-22.84$ $\mu \mathrm{g} / \mathrm{mL}$ ). Total sugar contents of the beverages varied from 6.29 to 10.97 $\mathrm{g} / 100 \mathrm{~mL}$. They ranked as $\mathrm{CD}>\mathrm{SH}>\mathrm{IT}$ according to the sugar contents. Gallic, vanilic, and caffeic acids, (+)-catechin and (-)-epigallocatechin gallate were determined in all beverages whereas p-coumaric, ferulic and sinapic acids, myricetin, quercetin, (-)-epigallocatechin and (-)epicatechin gallate could no detected in $\mathrm{CD}$ and $\mathrm{SH}$. The phenolic compound contents in IT were more than in $\mathrm{CD}$ and $\mathrm{SH}$ for all investigated compounds. The storage conditions caused to alterations in beverage $\mathrm{pH}$, acidities, TP contents and DPPH inhibitions.

Conclusions. Minerals, total phenolic contents, antioxidant capacities and individual phenolic compounds in the beverages increased depending on used sour grape concentrate rising ratios. Gallic acid was the most abundant phenolic acid in the beverages and (-)epicatechin for IT samples was the most abundant flavonol. The beverages $\mathrm{pH}$, acidity, total phenolic content and DPPH inhibition can change depending on storage temperatures and duration. 


\section{Introduction}

Beverage sector, is a sub-sector in food industry, has an important place in the world food production and trade (Guimaraes et al., 2012). Alcohol free, carbonated or noncarbonated drinks are generally called as soft drinks. In recent, manufacturing of fruit drinks and some iced drinks, various fruits and their flavors are often used according to consumer demands for competition in sector. In addition, studies on innovative drinks and additives have been performing by many researchers (Balaswamy et al., 2011; Gonzalez-Molina et al., 2012; Guimaraes et al., 2012; Jori et al., 2013; Verma et al., 2014; Jooyandeh 2015). Sour grape concentrate based beverages can also be in these innovative drink groups.

In recent years, consumer demands for beverages that contain some components positively affecting health as well as basic nutrition have increased. Especially, beverages having high functional properties are more preferred by consumer. Nanasombat et al. (2015) stated that functional foods and beverages are products offering functional health benefits. The functional beverages have a wide variety such as performance and energy beverages, whey beverages, fruit and vegetable smoothies, ready to drinks, vitamin and ingredient fortified drinks, and innovative fruit juices. As people's awareness and educational level increases, demand to functional beverages also rises. The reason for this increase is that these beverages have minerals, vitamins and antioxidant compounds, which may help to defend against oxidative stress and some other health problems.

Grape is rich fruit in terms of polyphenols. Polyphenols have important effect on product quality and have antioxidant properties. Moreover, the polyphenols show preservative effects against oxidation and microbial spoilage in foods (Singleton et al., 1978). The phenolic compounds primarily distribute in the skin, stem, leaf and seed of grape, rather than pulp (Pastrana-Bonillaet al., 2003; Makris et al., 2008; Xia et al., 2010). Proanthocyanidins, anthocyanins, flavonols, flavanols, resveratrols and phenolic acids are among the grape phenolic compounds. Flavonoids include flavan-3-ols, flavonols and anthocyanins. The flavanoids have many biological activities such as inhibition of plasma platelet aggregation, radical scaving activity and exhibiting antibacterial, antiviral, antiallergenic effects (Cook et al., 1996; Yang et al., 2009). The phenolic compounds are also in the sour grape such as ripened grape, but their amounts vary depending on maturity, variety, soil and environmental conditions (Sabir et al., 2010).

Sour grapes have been used to produce verjuice and fresh beverages as traditional in Turkey and other viticulture countries for a long time. Although they have high potential for beverages production, there is very limited knowledge about their usability in nonalcoholic beverages. In addition, using of the sour grapes in the beverages are almost nonexistent and it has been no encountered their using in carbonated and iced tea beverages up to now.

Besides, no study could be found regarding physiochemical properties, antioxidant activities, phenolic profiles, sugars and minerals in the sour grape based beverages and their quality alterations during storage. Monitoring of changes on quality during the storage period in each developed product is very important in terms of both shelf life and nutrient loss since storage time and temperature can be effect on food and beverage quality.

This study investigates possibility to use of the sour grapes in preparation of nonalcoholic beverages; physicochemical properties, content of phenolic compounds, sugars, minerals and antioxidant capacity of the new manufactured beverages; changes of some physical and chemical parameters of during their storage. 


\section{- Food Technology -}

\section{Materials and methods}

\section{Materials}

Sultani Çekirdeksiz ( $V$. vinifera L.) grapes were used to obtain sour grape concentrate. The sour grapes were harvested in Manisa Viticulture Research Institute vineyards. In addition, beverages manufacturing were performed at the same Institute pilot grape products processing unit.

\section{Beverage manufacturing}

Sour grape concentrate (SGC) using for beverages manufacturing was firstly produced. To produce this concentrate, sour Sultani Çekirdeksiz ( $V$. vinifera L.) grapes were harvested and then, stalks discarded and immediately crushed. The mash was pressed, and juice was clarified by using pectolytic enzyme, bentonite, gelatin and kieselsol. Then, sour grape juice was concentrated under vacuum. In the SGC production, the traditional wellknown clarification and vacuum evaporation processes were performed. The concentrate was stored at $-18{ }^{\circ} \mathrm{C}$ until using for beverage processing. The beverages manufacturing flow diagrams are shown in Figure 1.

The sugar syrup (50 ${ }^{\circ}$ brix) was prepared and mixed with SGC that was added at three different ratios for manufacturing carbonated drinks (CD). Then, these mixtures were diluted to $10^{\circ} \mathrm{Brix}$ by using carbonated water and following that filling/sealing process was carried out. The bottles were closed with crown caps. As preservative, $250 \mathrm{mg} / \mathrm{L}$ sorbic acid and 150 $\mathrm{mg} / \mathrm{L}$ benzoic acid were added. The sugar/acid (taste) balance were set as 35, 40 and 45 in the final CD beverages, respectively.

In the manufacturing of the sherbets $(\mathrm{SH}), 10^{\circ}$ Brix sugar syrup and SGC were mixed to produce beverages that were 20,25 and 30 sugar/acid taste balance. $250-\mathrm{mL}$ bottles were filled with sherbets and closed with crown caps. Pasteurization was done at $85^{\circ} \mathrm{C}$ for $15 \mathrm{~min}$ at once.

The 750 g black tea (brand Çaykur Kamelya) was brewed for 15 minutes, and then it was diluted 2 times with boiled water for preparing ice tea (IT). Then, by adding sugar syrup to the diluted brewed tea mixing, ice tea beverages that were 6,7 and $8{ }^{\circ}$ Brix were obtained. SGC was added as equal amounts to these beverages. The taste balance in final ice tea beverages were adjusted 30, 35 and 40, respectively. Filled and bottled samples were pasteurized at $85^{\circ} \mathrm{C}$ for $15 \mathrm{~min}$ at once. The beverages descriptions were indicated in Table 1.

Table 1

Beverage descriptions

\begin{tabular}{|l|c|c|}
\hline Beverages & Soluble Solids, ${ }^{\circ}$ Brix & Taste Balance, ${ }^{\circ}$ Brix/Acidity \\
\hline CD1 & 10.0 & 45.0 \\
\hline CD2 & 10.0 & 40.0 \\
\hline CD3 & 10.0 & 35.0 \\
\hline SH1 & 10.0 & 20.0 \\
\hline SH2 & 10.0 & 25.0 \\
\hline SH3 & 10.0 & 30.0 \\
\hline IT1 & 6.0 & 30.0 \\
\hline IT2 & 7.0 & 35.0 \\
\hline IT3 & 8.0 & 40.0 \\
\hline
\end{tabular}




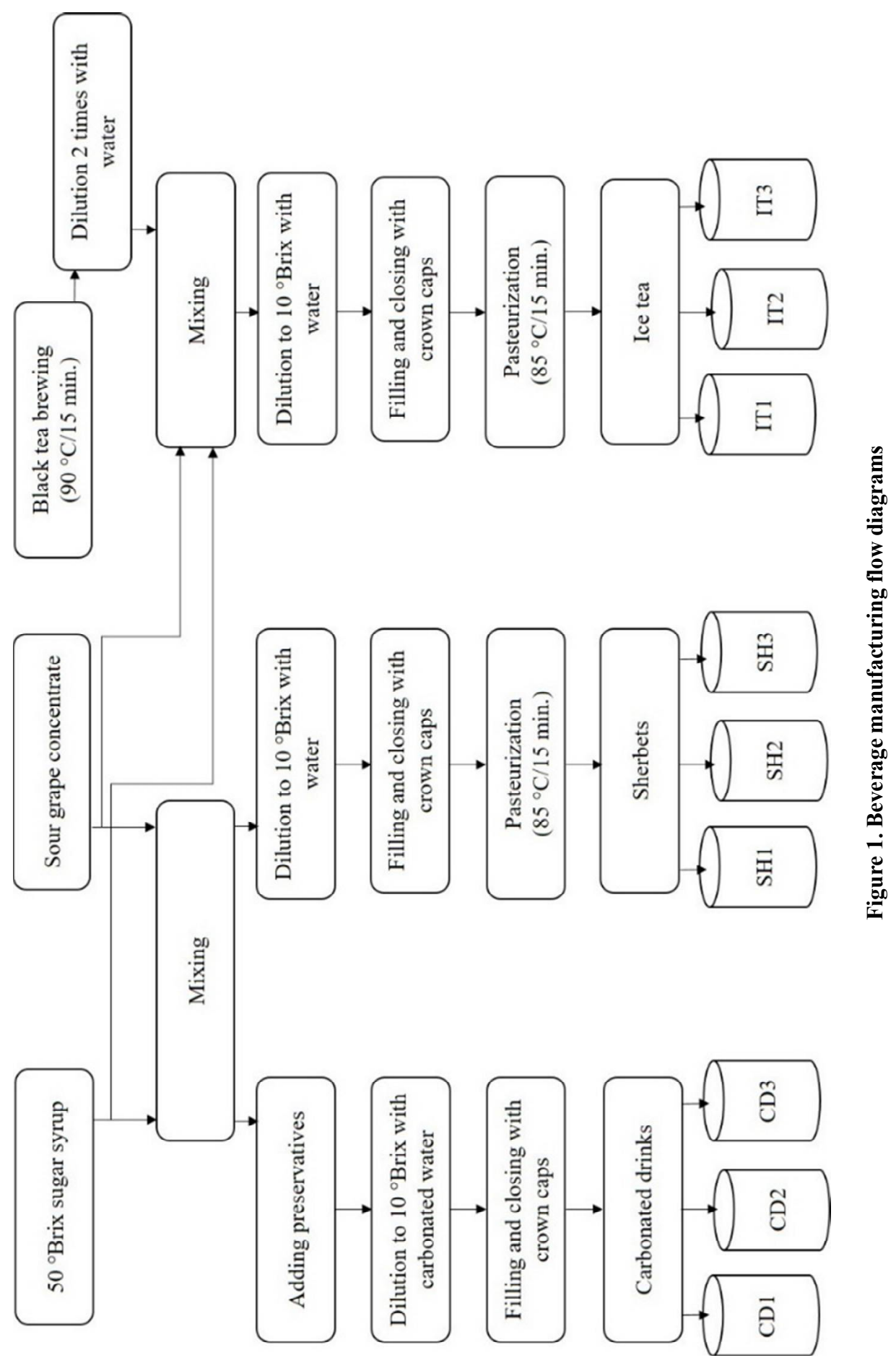




\section{- Food Technology -}

\section{Determination of the physicochemical parameters, transmittances and colors}

The $\mathrm{pH}$ values were measured by using a $\mathrm{pH}$ meter (Hanna 211). The titratable acidity was determined by titrating of $10 \mathrm{~mL}$ of sample with $0.1 \mathrm{~N} \mathrm{NaOH}$ to $\mathrm{pH} 8.1$ and expressed as tartaric acid percent (Ough et al., 1998).

The transmittance values were calculated by using the samples absorbance that were measured at $400 \mathrm{~nm}$ according to below formula. Distilled water was used as blank (Artık et al., 1996).

$$
\log T=2-A
$$

Spectrophotometric method was used to determine colors of samples (AOCS, 1999). Briefly, $350 \mu \mathrm{l}$ sample was filled to micro-plate cell and absorbance was read using by Multiskan FC Microplate Spectrophotometer (Thermo Scientific, Multiskango, Finland) at 420, 520 and $620 \mathrm{~nm}$. Distilled water was used as blank. Color intensity (CI) and optic density (OD) at 420, 520 and $620 \mathrm{~nm}$ were calculated according to below formulas:

$$
\begin{aligned}
\mathrm{CI} & =\mathrm{A}_{420}+\mathrm{A}_{520}+\mathrm{A}_{620} \\
\mathrm{OD}_{420} & =\left(\mathrm{A}_{420}\right) / \mathrm{CI} \times 100 \\
\mathrm{OD}_{520} & =\left(\mathrm{A}_{520}\right) / \mathrm{CI} \times 100 \\
\mathrm{OD}_{620} & =\left(\mathrm{A}_{620}\right) / \mathrm{CI} \times 100
\end{aligned}
$$

where $\mathrm{OD}_{420}$ represent yellowness, $\mathrm{OD}_{520}$ redness and $\mathrm{OD}_{620}$ blueness.

\section{Determination of total polyphenolic content}

Total polyphenolic contents (TPC) of the samples were determined according to FolinCiocalteu colorimetric method (Singleton et al., 1965). At first, $100 \mu \mathrm{L}$ of reagent solution was added to each samples and the volume were completed to $4 \mathrm{~mL}$ and then $500 \mu \mathrm{L}$ of $20 \%$ saturated sodium carbonate $\left(\mathrm{Na}_{2} \mathrm{CO}_{3}\right)$ was added to final solution after 3 min and all of them was shaken. Then, the samples were incubated at room temperature $(24 \pm 1){ }^{\circ} \mathrm{C}$ for $30 \mathrm{~min}$. At the end of the duration, $350 \mu \mathrm{L}$ of samples were transferred in a 96 well of microplate and absorbance was measured at $760 \mathrm{~nm} .25,50,100,200$ and $400 \mathrm{mg} / \mathrm{L}$ of standard concentrations were used for calibration curve. Results were expressed as Gallic acid equivalent in L (mgGAE/L).

\section{Antioxidant capacity}

FRAP, CUPRAC and ABTS assays (Benzie et al., 1999; Re et al., 1999; Apak et al., 2004; Callaghan et al., 013; Wern et al., 2016) were used to determine antioxidant capacity of the beverages. In addition, DPPH assay (Brand-Williams et al., 1995) was performed to measure radical scavenging activity of beverages during storage.

\section{ABTS•+ method}

2,2'-azinobis-(3-ethylbenzothiazoline-6- sulfonic acid (ABTS•+) method that was described by Re et al. (1999) was used. At first, $7 \mathrm{mM}$ ABTS and $2.45 \mathrm{mM}$ potassium persulfate were mixed and incubated at room temperature 12-16 h. ABTS •+ solution was diluted by adding ethanol till $0.700( \pm 0.02)$ absorbance at $734 \mathrm{~nm}$. Then, diluted sample $(60$ $\mu \mathrm{L})$ was added to $940 \mu \mathrm{L} \mathrm{ABTS} \bullet+$ reagent. The absorbance of these solution was read (t:0 and $6 \mathrm{~min}$ ) by using spectrophotometer (Thermo scientific, Multiskango, Finland). A 


\section{- Food Technology -}

calibration graphic was used to calculate results and they was expressed as $\mu \mathrm{M}$ Trolox equivalent (TE) in liter beverage.

\section{FRAP method}

The ferric reducing antioxidant power (FRAP) of the samples were determined according to the protocol that described by Benzie and Strain (1999) and modified by Wern et al. (2016). At first, $300 \mathrm{mM}$ acetate buffer $\left(3.1 \mathrm{~g} \mathrm{C}_{2} \mathrm{H}_{3} \mathrm{NaO}_{2} \cdot 3 \mathrm{H}_{2} \mathrm{O}\right.$ and $\left.16 \mathrm{~mL} \mathrm{C}_{2} \mathrm{H}_{4} \mathrm{O}_{2}\right), 10$ $\mathrm{mM}$ TPTZ (2, 4, 6-tripyridyl-s-triazine) in $40 \mathrm{mM} \mathrm{HCl}$, and $20 \mathrm{mM} \mathrm{FeCl}{ }_{3} \cdot 6 \mathrm{H}_{2} \mathrm{O}$ were prepared for the FRAP reagent. Then, $25 \mathrm{~mL}$ acetate buffer $(3.6 \mathrm{pH}), 2.5 \mathrm{~mL}$ TPTZ, and 2.5 $\mathrm{mL} \mathrm{FeCl} \cdot 6 \mathrm{H}_{2} \mathrm{O}$ were mixed to obtain a fresh reagent. The FRAP reagent, distilled water, and the samples were warmed to $37^{\circ} \mathrm{C}$. Then, $50 \mu \mathrm{L}$ of sample and FRAP reagent were added to $2 \mathrm{~mL}$ distilled water at $37{ }^{\circ} \mathrm{C}$, and the mixture was incubated for $4 \mathrm{~min}$ at the same temperature in dark. The mixture absorbance was read by a Uv-vis spectrophotometer at 593 $\mathrm{nm}$ for eight min. 50-1,000 $\mu \mathrm{M}$ standard Trolox concentrations were used for the calibration graphic, and the results were expressed as $\mu \mathrm{M}$ TE in liter beverage.

\section{CUPRAC assay}

Cupric reducing antioxidant capacity (CUPRAC) assay that was described by Apak et al. (2004) and modified for adaptation to grape products by Callaghan et al. (2013) was utilized. $150 \mu \mathrm{L}$ of $1 \mathrm{M}$ ammonium acetate, $7.5 \mathrm{mM}$ neocuproine, and $10 \mathrm{mM}$ copper (II) chloride dehydrate were added to $150 \mu \mathrm{L}$ samples that were diluted by $0.05 \mathrm{M}$ Tris buffer ( $\mathrm{pH}$ 7.6). Then, they were incubated at room temperature during $30 \mathrm{~min}$. After incubation, their absorbance values were measured by using a Uv-vis spectrophotometer at $450 \mathrm{~nm}$. Blank was Tris buffer. Trolox concentration ranged 50 to $1,000 \mu \mathrm{M}$ to obtain the calibration graphic. The results were given as $\mu \mathrm{M}$ TE in liter drinks.

\section{DPPH radical scavenging assay}

2,2-Diphenyl-1-picrylhydrazyl (DPPH) method analysis was performed according to Brand-Williams et al. (1995). The principle of the method is regarding the measurement of the reduction ability of the DPPH • radical on samples. $3 \mathrm{ml}$ of the $1 \mathrm{mM}$ DPPH• solution was transferred and 200,400,600, 800 and $1000 \mu$ of diluted samples were added and standardized to $4 \mathrm{ml}$ solution with methanol and incubated at room conditions $\left(24 \pm 1^{\circ} \mathrm{C}\right)$ in dark. Methanol was used as blank solvent. Then, the absorbance was measured at $517 \mathrm{~nm}$ wavelength by spectrophotometer. Percent inhibition values were calculated according to blank absorbance as described the formula as shown below:

$$
\text { Inhibition, } \%=\left(\left(\mathrm{A}_{\mathrm{DPPH}}-\mathrm{A}_{\mathrm{SAMPLE}}\right) / \mathrm{A}_{\mathrm{DPPH}}\right) \times 100
$$

\section{Determination of mineral content}

Atomic Absorption Spectroscopy (Perkin Elmer, Analiyst 400, USA) method was used to determine mineral compositions of the samples (AOCS, 1999). At first, samples were kept at $500-600{ }^{\circ} \mathrm{C}$ to obtain ash. Then, they were solved with $\mathrm{HNO}_{3}$ and $\mathrm{HCl}$ and diluted by distilled water to $100 \mathrm{~mL}$. Potassium $(\mathrm{K})$, calcium $(\mathrm{Ca})$, magnesium $(\mathrm{Mg})$, sodium $(\mathrm{Na})$, iron $(\mathrm{Fe})$, zinc $(\mathrm{Zn})$, mangane $(\mathrm{Mn})$ and copper $(\mathrm{Cu})$ amounts of the samples were determined and given as $\mu \mathrm{g}$ in $\mathrm{mL}$ sample. 


\section{- Food Technology -}

\section{Determination of sugars}

The sugars of the beverages were found with slight modifications to the method described by Castellari et al. (2000). At first, beverage samples were diluted distilled water and passed through a PTFE $0.45 \mu \mathrm{m}$ syringe filter. Then, they were injected into high performance liquid chromatography (HPLC) system (Agilent 1260) for measuring. The detector was selected as the refractive index (RID), and the column was $\mathrm{NH}_{2} 250 \times 4.6 \mathrm{~mm}$, $5 \mu \mathrm{m}$ (Inertsil). Temperature of the column was set to $30{ }^{\circ} \mathrm{C}$ and injection volume was used as $20 \mu \mathrm{L}$. The elution time was $18 \mathrm{~min}$, flow rate was $1.5 \mathrm{~mL} / \mathrm{min}$ and flow was isocratic. The mobile phase consisted of acetonitrile and distilled water $(80: 20 ; \mathrm{v}: \mathrm{v})$. The sugars of the samples were identified by comparing their retention times and spectra with those of analytical standards. The concentration of the sugars was calculated using the calibration curves and expressed as $\mathrm{g}$ in the $100 \mathrm{~mL}$.

\section{Determination of phenolic compounds}

HPLC phenolic compound analysis were performed on Agilent 1260 system. The system is equipped with a diode-array UV detector (DAD). It consists of a quart pump, a degasser, an auto sampler and a column oven. Software program is Agilent lab advisor chemstation. C18 ODS column $(250 \times 4.6 \mathrm{~mm}, 5 \mu \mathrm{m})$ was selected for the separation (Agilent).

In the analyzing of the flavanols, isocratic elution was performed using methanol, distilled water and formic acid (19.5:80.2:0.3) as mobile phase during 35 minutes at 280 wavelength. The column temperature was set to $40{ }^{\circ} \mathrm{C}$ and flow rate was $1 \mathrm{~mL} / \mathrm{min}$. The beverage samples were diluted to certain ratio by mobile phase and passed through a $0.45 \mu \mathrm{m}$ PTFE syringe filter and then injected to system as $5 \mu \mathrm{L}$.

To determine the phenolic acids and flavonols, HPLC analysis was performed with a gradient elution with little modifications according to Porgalı et al. (2012) and Natividade et al. (2013). The column temperature was set to $30{ }^{\circ} \mathrm{C}$ and flow rate was $1 \mathrm{~mL} / \mathrm{min}$. The injection volume and flow rate were $5 \mu \mathrm{L}$ and $1 \mathrm{ml} / \mathrm{min}$, respectively. The detection wavelength was $280 \mathrm{~nm}$ for vanilic acid, $320 \mathrm{~nm}$ for p-coumaric acid, caffeic acid, ferulic acid and sinapic acid, $360 \mathrm{~nm}$ for myricetin and quercetin. The mobile phases consisted of A: formic acid and distilled water (99.8:0.2) and B: acetonitrile and formic acid (99.8:0.2). The gradient elution was as follows: the initial elution $0 \% \mathrm{~B}$, followed $3 \mathrm{~min}$ by linear gradient from $0 \%$ to $10 \% \mathrm{~B}, 19$ min linear gradient to $13.5 \% \mathrm{~B}, 4$ min linear gradient to $18.5 \% \mathrm{~B}, 10 \mathrm{~min}$ elution to $30 \% \mathrm{~B}, 9$ min elution to $40 \% \mathrm{~B}, 7$ min gradient elution to $5 \% \mathrm{~B}$ and $6 \mathrm{~min}$ isocratic elution step $5 \% \mathrm{~B}$. Then, $2 \mathrm{~min} \% 100 \mathrm{~A}$ was performed for returning to initial condition.

The phenolic compounds were identified by comparing their retention times and spectra with those of analytical standards. The concentration of phenolic compounds in the samples was calculated using by the calibration curves and expressed as $\mu \mathrm{g} / \mathrm{mL}$. Chromatographic analyses were performed in triplicate.

\section{Storage}

Manufactured $\mathrm{CD}, \mathrm{SH}$ and IT beverages were stored at three different storage temperatures $\left(4,20\right.$ and $\left.24{ }^{\circ} \mathrm{C}\right)$ during six months. They were analysed to determine the changing of some quality parameters initially and each two months during storage time. The common drink storage conditions were preferred monitoring of the alterations in the beverages. 


\section{Statistical analysis}

The variance analysis (ANOVA) was applied to the obtained results. Duncan multiple comparison test was performed to determine the differences between the mean values ( $<<0.05$ significance level was used for comparisons). The statistical analysis was performed to Granato et al. (2014).

\section{Sensorial Analysis}

A sensorial scoring test was used to determine the beverages sensorial properties (Altuğ et al., 2005). All samples were evaluated in terms of color, taste and general appreciate by seven panellists who had experiences. The samples were scored 5 (best) from to 0 (worst).

\section{Results and discussion}

\section{Physical parameters of the beverages}

The drinks physical properties such like color, clarity and appearance effect on general appreciation and being preference. The color and transmittance values of produced beverages were shown in Table 2.

There were no statistical differences between $\mathrm{OD}_{420}, \mathrm{OD}_{520}$ and $\mathrm{OD}_{620}$ values in $\mathrm{CD}$ and $\mathrm{SH}$. The abundant color characteristic was yellowness in $\mathrm{CD}$. In SH beverages, the yellowness, redness and blueness varied from 61.85 to $63.23,25.95$ to 26.74 and 10.83 to 11.4 , respectively. SGC ratios caused to these color variations. The significant statistical differences were found between IT $\mathrm{OD}_{420}, \mathrm{OD}_{520}$ and $\mathrm{OD}_{620}$ values $(\mathrm{p}<0.05)$. IT beverages had more redness than $\mathrm{CD}$ and $\mathrm{SH}$, and this was caused by using black tea. On the other hand, yellowness and blueness in IT beverages were lower.

\section{Color and transmittance values of the beverages}

Table 2

\begin{tabular}{|c|c|c|c|c|}
\hline Beverages & $\mathrm{OD}_{420}$ & OD $_{520}$ & OD $_{620}$ & Transmittances \\
\hline CD1 & 94.79 & 5.21 & - & $92.54^{\mathrm{a}}$ \\
\hline CD2 & 94.60 & 5.40 & - & $91.39^{\mathrm{ab}}$ \\
\hline CD3 & 100.00 & - & - & $90.08^{\mathrm{b}}$ \\
\hline SH1 & 61.85 & 25.95 & 11.41 & $79.17^{\mathrm{a}}$ \\
\hline SH2 & 62.69 & 26.30 & 11.01 & $74.34^{b}$ \\
\hline SH3 & 63.23 & 26.74 & 10.83 & $66.86^{\mathrm{c}}$ \\
\hline IT1 & $22.37^{\mathrm{a}}$ & $67.91^{b}$ & $9.72^{\mathrm{a}}$ & 0.80 \\
\hline IT2 & $22.15^{\mathrm{b}}$ & $68.95^{\mathrm{a}}$ & $8.90^{\mathrm{b}}$ & 0.77 \\
\hline IT3 & $22.48^{\mathrm{a}}$ & $67.94^{b}$ & $9.58^{\mathrm{a}}$ & 0.70 \\
\hline
\end{tabular}

* The values indicating with different letters are statistically different for each beverage group in the each column $(p<0.05)$.

The transmittance percentages were calculated by measuring absorbance at $410 \mathrm{~nm}$ for determination of the beverage clarity. In $\mathrm{CD}$ and $\mathrm{SH}$, the significant statistical differences were observed in terms of transmittance percentages. The best clarity values were in $\mathrm{CD}$ samples. The SH transmittance values were lower than $\mathrm{CD}$. The used concentrate adding 
amounts affected the beverage clarity. The using of black tea and concentrate caused the increase of turbidity in IT samples. For this reason, the lower clarity values were found in them. The used ingredients in the production process affected the color and clarity of the beverages.

\section{Minerals in the beverages}

Table 3 shows the mineral composition of the beverages. Four major ( $\mathrm{K}, \mathrm{Mg}, \mathrm{Ca}, \mathrm{Na})$ and minor $(\mathrm{Fe}, \mathrm{Zn}, \mathrm{Mn}, \mathrm{Cu})$ mineral are investigated. The significant statistical differences were found for $\mathrm{K}, \mathrm{Ca}, \mathrm{Mg}$ and $\mathrm{Na}$ contents in $\mathrm{CD}$ samples and for $\mathrm{K}, \mathrm{Mg}, \mathrm{Na}, \mathrm{Zn}$ and $\mathrm{Cu}$ contents in SH samples $(\mathrm{p}<0.05)$, but there were no differences in the other minerals. The $\mathrm{K}$ contents in the beverages varied between 2.59 and $45.25 \mu \mathrm{g} / \mathrm{mL}$. IT samples had more $\mathrm{K}$ content than $\mathrm{CD}$ and $\mathrm{SH}$. The $\mathrm{K}$ is one of the most important mineral for human health and World Health Organization suggests $3510 \mathrm{mg} \mathrm{K}$ intake of at least daily for adult (WHO, 2021). So, the sour grape based beverages, especially IT, can be considered as K source in daily diet. The Ca contents ranged from 159.03 to $358.25 \mu \mathrm{g} / \mathrm{mL}$ in these beverages and it was higher than in others. This difference was due to the using of different water sources. The same water source was used for SH and IT, but the CD was made using carbonated water from a local factory.

Mineral compositions of the beverages $(\mu \mathrm{g} / \mathrm{mL})$

Table 3

\begin{tabular}{|l|c|c|c|c|c|c|c|c|}
\hline Beverages & K & Ca & Mg & Na & Fe & Zn & Mn & Cu \\
\hline CD1 & $2.59^{\mathrm{b}}$ & $297.28^{\mathrm{b}}$ & $41.65^{\mathrm{c}}$ & $77.41^{\mathrm{b}}$ & 10.26 & 1.39 & 3.09 & 2.96 \\
\hline CD2 & $3.98^{\mathrm{b}}$ & $349.50^{\mathrm{a}}$ & $55.73^{\mathrm{b}}$ & $86.74^{\mathrm{b}}$ & 8.74 & 1.18 & 3.87 & 2.78 \\
\hline CD3 & $7.59^{\mathrm{a}}$ & $358.25^{\mathrm{a}}$ & $64.12^{\mathrm{a}}$ & $120.80^{\mathrm{a}}$ & 16.69 & 1.58 & 2.07 & 5.47 \\
\hline \multicolumn{7}{|c|}{} \\
\hline SH1 & $13.90^{\mathrm{a}}$ & 178.33 & $34.16^{\mathrm{a}}$ & $465.13^{\mathrm{a}}$ & 19.61 & $3.01^{\mathrm{a}}$ & 2.02 & $3.40^{\mathrm{a}}$ \\
\hline SH2 & $10.45^{\mathrm{b}}$ & 163.50 & $30.45^{\mathrm{ab}}$ & $246.95^{\mathrm{b}}$ & 18.43 & $1.67^{\mathrm{b}}$ & 1.84 & $1.76^{\mathrm{b}}$ \\
\hline SH3 & $6.87^{\mathrm{c}}$ & 177.63 & $26.55^{\mathrm{b}}$ & $199.38^{\mathrm{b}}$ & 22.84 & $2.12^{\mathrm{b}}$ & 1.75 & $1.73^{\mathrm{b}}$ \\
\hline \multicolumn{7}{|c|}{} \\
\hline IT1 & 45.25 & 159.03 & 16.63 & 692.28 & 10.15 & 1.59 & 4.77 & 0.93 \\
\hline IT2 & 33.82 & 190.58 & 19.73 & 481.7 & 8.74 & 2.69 & 3.49 & 1.18 \\
\hline IT3 & 36.31 & 173.95 & 17.52 & 428.78 & 14.5 & 2.05 & 4.53 & 0.93 \\
\hline
\end{tabular}

* The values indicating with different letters are statistically different for each beverage group in the each column $(\mathrm{p}<0.05)$.

The Mg contents of CD samples were higher than in other beverages. The Mg contents increased depending on SGC adding ratios. There was lower $\mathrm{Mg}$ amount in IT beverages because of this. Na contents varied from 77.41 to $692.28 \mu \mathrm{g} / \mathrm{mL}$. SH and IT samples had more $\mathrm{Na}$ than $\mathrm{CD}$ beverages, and this may have caused from $\mathrm{d}$ used dilution water. Fe contents ranged from 8.74 to $22.84 \mu \mathrm{g} / \mathrm{mL}$ in beverages and it was the most abundant mineral in the micro minerals. The $\mathrm{Mn}, \mathrm{Zn}$ and $\mathrm{Cu}$ contents were lower than other minerals in the beverages. Their contents changed 1.755-4.77, $1.18-3.01$ and $0.93-3.40 \mu \mathrm{g} / \mathrm{mL}$, respectively. In the beverage formulation, the ingredient choosing is an important that it affected the mineral composition. In a previous study, Silva et al. (2019) studied to determine macro and micronutrient elements contents from soft drinks. While our $\mathrm{K}$ results are similar with their findings, the other mineral findings are little higher. The beverages mineral contents extremely depend on used the base plant material in production process. In addition, manufacturing 
process stages, packaging or bottling and using additives have less extent on the mineral concentration (Silva et al.; 2019). These differences may be caused by using of different raw materials.

\section{Total phenolic contents and antioxidant properties of the beverages}

TP and antioxidant capacities of the CD and SH beverages are shown in Figure 2 and 3, respectively. The significant statistical differences were determined in terms of TP $(p<0.05)$ in $\mathrm{CD}$ and $\mathrm{SH}$ beverages, but no observed in IT ( $\mathrm{p}>0.05$ ). TP content in IT was approximately tenfold higher than in CD and SH due to using of black tea in formulation. The TP amounts were lower than in previous literature (Lugasi et al., 2003; Brenna et al., 2009; Wu et al., 2011).

Antioxidant capacities of the $\mathrm{CD}$ and $\mathrm{SH}$ samples increased depending on the used concentrate amounts in all 3 methods. However, these results no changed in the IT samples because of used the same concentrate ratios. The CD antioxidant capacities ranged from 186 to $228 \mu \mathrm{M}$ TE/L, 124 to $155 \mu \mathrm{M}$ TE/L and 66 to $77 \mu \mathrm{M}$ TE/L for FRAP, CUPRAC and ABTS assays, respectively. Brenna et al. (2009) studied on antioxidant capacity of some caramelcontaining soft drinks and they reported FRAP assay had lower sensitivity than DPPH assay in cola drinks. The FRAP, CUPRAC and ABTS assays had the similar sensitivity according to our findings in CD beverages. On the other hand, many researchers (Nikfardjam, 2008; Piva et al., 2008; Gollücke et al., 2009; Hayoglu et al., 2009; Öncül et al., 2015; Turkmen et al., 2017; Guler et al., 2018) have expressed that grape and sour grape juice or concentrate had high antioxidant activity. For this reason, the using of SGC increased the phenolic content and antioxidant capacity of CD samples. The SH samples antioxidant capacities varied between 213 and $298 \mu \mathrm{M}$ TE/L, 149 and $214 \mu \mathrm{M}$ TE/L and 94 and $138 \mu \mathrm{M}$ TE/L for FRAP, CUPRAC and ABTS assays, respectively. These values changed depending on SGC in formulation. Moreover, it can be expressed there are a strong correlation between antioxidant capacity and SGC ratio.

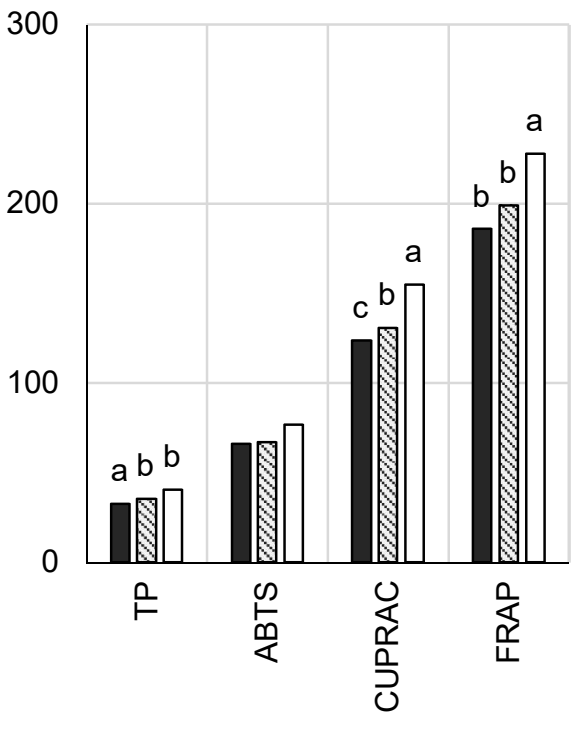

$\square \mathrm{CD} 1 \otimes \mathrm{CD} 2 \square \mathrm{CD} 3$

Figure 2.

TP and antioxidant capacities in CDs

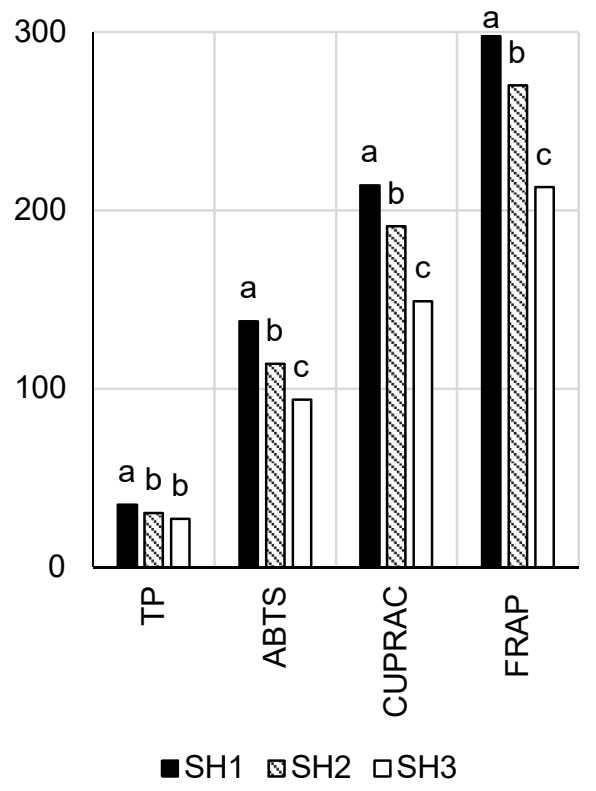

Figure 3.

TP and antioxidant capacities in SHs 
Antioxidant capacities of the IT samples ranged from 3868 to $4319 \mu \mathrm{M}$ TE/L, 4436 to $4893 \mu \mathrm{M}$ TE/L and 2620 to $2800 \mu \mathrm{M}$ TE/L for FRAP, CUPRAC and ABTS assays, respectively. There was no observed significant statistical differences among samples because of using the same SGC ratios in IT formulation. In IT production, only the sugar ratios were changed. Pekal et al. (2011) studied on antioxidant properties of fruit, flavoured black teas, and expressed that flavoured teas had higher antioxidant properties than fruit teas for DPPH assay and aromatized teas exhibit the highest antioxidant properties in CUPRAC assay. These findings support our results and study.

\section{Sugar compositions of the beverages}

Sugar is an important food component. It is naturally found in many foods, and used widely in industry (Zaitoun et al., 2018). It primary provides sweetness and energy in food products, and has a very important role in formation the texture and color, as well as in fermentation and preservation (Rosa et al., 2009). The sugar compositions of beverages are presented in Figure 4.

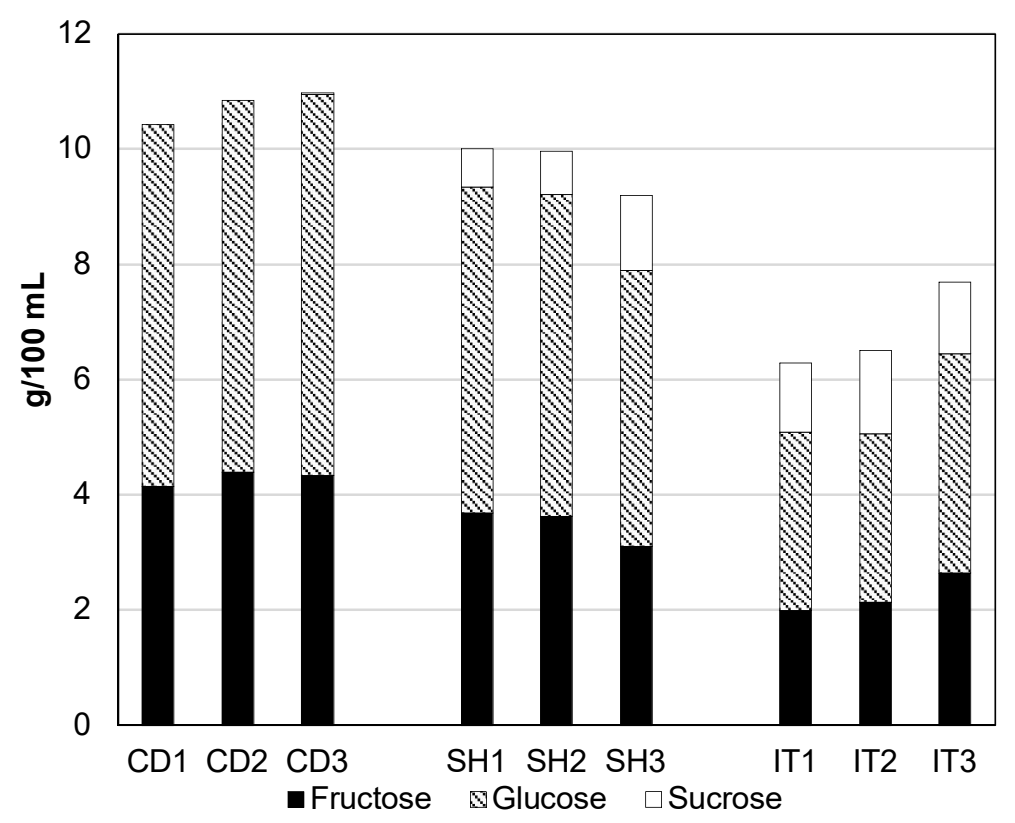

Figure 4. Sugar compositions of the beverages

The total sugar contents of CD, SH and IT beverages varied from 10.42 to $10.97,9.20$ to 10.00 and 6.29 to $7.69 \mathrm{~g} / 100 \mathrm{~mL}$, and the glucose-fructose ratios were ranged between 1.47 and 1.52, 1.53 and 1.54 and 1.37 and 1.55 in the CD, SH and IT, respectively. According to the ratios, the content of glucose is higher than fructose in the beverages, it can be thought that this is caused by both used of sour grape concentrate and sucrose inversion to have being during the preparation of syrup. Sabir et al. (2010) announced that grape has higher content of glucose than fructose in unripe stage. Sugar content of samples were set according to beverage group and market products. It has been tried to use the low sugar amount in the 


\section{- Food Technology -}

produced beverages since the increase of consuming sugar leads to several diseases. The sugar content was kept constant to reach the target taste balance in $\mathrm{CD}$ and SH beverages, but they were changed in IT samples because of SGC ratios constant. In this study, it was used unripe sour grapes to obtain the concentrate that was added to provide flavour and acid to the beverages. Our findings compatible with the previous literature.

\section{Individual phenolic compounds in the beverages}

The phenolic acid, flavanol and flavonol compounds were determined in SGC based beverages and their results were shown in Table 4.

Phenolic compounds in the beverages $(\mu \mathrm{g} / \mathrm{mL})$

Table 4

\begin{tabular}{|c|c|c|c|c|c|c|c|c|c|}
\hline Compounds & CD1 & CD2 & CD3 & SH1 & SH2 & SH3 & IT1 & IT2 & IT3 \\
\hline Gallic acid & $1.15^{\mathrm{c}}$ & $1.80^{\mathrm{b}}$ & $2.52^{\mathrm{a}}$ & 0.66 & 0.22 & 0.17 & 76.40 & 77.13 & 76.10 \\
\hline Vanilic acid & $0.30^{\mathrm{b}}$ & $0.34^{\mathrm{b}}$ & $0.45^{\mathrm{a}}$ & $0.34^{\mathrm{a}}$ & $0.32^{\mathrm{a}}$ & $0.25^{\mathrm{b}}$ & $1.63^{\mathrm{a}}$ & $1.34^{\mathrm{b}}$ & $1.64^{\mathrm{a}}$ \\
\hline Caffeic acid & $0.15^{\mathrm{b}}$ & $0.16^{\mathrm{b}}$ & $0.22^{\mathrm{a}}$ & $0.45^{\mathrm{a}}$ & $0.26^{\mathrm{b}}$ & $0.24^{\mathrm{b}}$ & $2.09^{\mathrm{a}}$ & $2.04^{\mathrm{b}}$ & $2.06^{\mathrm{ab}}$ \\
\hline p-Coumaric acid & $n d$. & $n d$. & $n d$. & $n d$. & $n d$. & $n d$. & 0.64 & 0.69 & 0.66 \\
\hline Ferulic acid & $n d$. & $n d$. & $n d$. & $n d$. & $n d$. & $n d$. & $2.60^{\mathrm{a}}$ & $2.20^{\mathrm{b}}$ & $2.42^{\mathrm{ab}}$ \\
\hline Sinapic acid & $n d$. & $n d$. & $n d$. & $n d$. & $n d$. & $n d$. & $5.74^{\mathrm{c}}$ & $5.93^{\mathrm{a}}$ & $5.84^{\mathrm{b}}$ \\
\hline Myricetin & $n d$. & $n d$. & $n d$. & $n d$. & $n d$. & $n d$. & 1.95 & 1.86 & 1.89 \\
\hline Quarcetin & $n d$. & $n d$. & $n d$. & $n d$. & $n d$. & $n d$. & $1.31^{\mathrm{b}}$ & $1.55^{\mathrm{a}}$ & $1.46^{\mathrm{a}}$ \\
\hline $\begin{array}{l}\text { (-)-Epigallo- } \\
\text { catechin }\end{array}$ & $n d$. & $n d$. & $n d$. & $n d$. & $n d$. & $6.80^{\mathrm{c}}$ & $55.57^{\mathrm{a}}$ & $52.49^{b}$ & $55.91^{\mathrm{a}}$ \\
\hline$(+)$-Catechin & $1.15^{\mathrm{c}}$ & $1.46^{\mathrm{a}}$ & $1.39^{\mathrm{a}}$ & $0.82^{\mathrm{a}}$ & $0.66^{\mathrm{b}}$ & $0.47^{\mathrm{c}}$ & 32.28 & 31.39 & 32.30 \\
\hline $\begin{array}{l}\text { (-)-Epigallo- } \\
\text { catechin- gallate }\end{array}$ & $0.76^{\mathrm{b}}$ & $0.90^{\mathrm{a}}$ & $1.01^{\mathrm{a}}$ & $1.90^{\mathrm{a}}$ & $1.51^{\mathrm{b}}$ & $1.48^{\mathrm{b}}$ & $30.98^{\mathrm{a}}$ & $31.25^{\mathrm{a}}$ & $29.46^{\mathrm{b}}$ \\
\hline (-)-Epicatechin & $n d$. & $n d$. & $n d$. & 3.79 & $n d$. & $n d$. & $75.14^{b}$ & $86.14^{\mathrm{a}}$ & $74.01^{b}$ \\
\hline $\begin{array}{l}\text { (-)-Epicatechin- } \\
\text { gallate }\end{array}$ & $n d$. & $n d$. & $n d$. & nd. & $n d$. & $n d$. & $16.43^{\mathrm{a}}$ & $16.95^{\mathrm{a}}$ & $11.05^{\mathrm{b}}$ \\
\hline
\end{tabular}

*The values indicating with different letters are statistically different for each beverage group in the each row $(\mathrm{p}<0.05)$.

**nd.: not detected

The gallic, vanilic and caffeic acids, (+)-catechin and (-)-epigallocatechin gallate were determined all beverages, but p-coumaric, ferulic and sinapic acids, myricetin, quercetin, ()-epigallocatechin and (-)-epicatechin gallate could no detected in the CD and SH beverages. In addition, (-)-epicatechin was only found SH1 and IT beverage samples. The phenolic compound quantities in IT samples were more than $\mathrm{CD}$ and SH beverages owing to using of black tea in the formulation. The most abundant phenolic acid was gallic acid that varied from 1.15 to $25.52,0.17$ to 0.66 and 76.1 to $77.13 \mu \mathrm{g} / \mathrm{mL}$ in the CD, SH and IT beverages, respectively. Nikfardjam (2008) reported that Iran sour grape juice had between 36.6 and $70.6 \mathrm{mg} / \mathrm{L}$ gallic acid. According to another study results, gallic acid content ranged from 1.05 to $1.85 \mathrm{mg} / 100 \mathrm{~g}$ DW during sour grape juice processing (Guler et al., 2018). The current study gallic acid findings in $\mathrm{CD}$ and $\mathrm{SH}$ beverages are lower than the previous literatures because of limited use of SGC in the formulation. On the other hand, the gallic acid content of black tea watery extract was determined as $0.216 \mathrm{mg} / 100 \mathrm{~mL}$ by Agca et al. (2020). Cabrera et al. (2003) expressed that black tea samples included between 2.5 and $4.5 \mathrm{mg} / \mathrm{g}$ gallic acid. In another study, it was presented that in Turkish black tea gallic acid contents 
were between 2.38 and $2.58 \mathrm{mg} / \mathrm{g}$ (Atalay et al., 2017). Furthermore, the fermentation and infusion conditions in tea production effect the phenolic compound contents such like gallic acid ((Fernandez et al., 2002; Zuo et al., 2002; Cabrera et al., 2003; Atalay et al., 2017). In addition, the preferred tea and fruit concentrate ratios in the formulation, dilution of infused tea and processing conditions can effect on phenolic content of the beverages. Especially, the infusion and dilution of the tea for iced tea manufacturing are one of the important processing stages.

In IT beverages, the primarily flavonol was (-)-epicatechin with $74.01-86.14 \mu \mathrm{g} / \mathrm{mL}$. The (-)-epigallocatechin, $(+)$-catechin, (-)-epigallocatechin gallate and (-)-epicatechin gallate followed to (-)-epicatechin in terms of quantity, respectively. The tea and SGC in the formulation increased the flavonols in IT beverages as expected. It is already known tea, grape and their derivative products are among the richest products in terms of polyphenols (Fernandez et al., 2002; Zuo et al., 2002; Cabrera et al., 2003; Nikfardjam, 2008; Sabir et al., 2010; Atalay et al., 2017; Turkmen et al., 2017; Guler et al., 2018; Guler et al., 2019; Agca et al., 2020).

(-)-Epigallocatechin gallate has higher antioxidant capacity than other catechins and is an important substance for human health and it has beneficial properties to prevent metabolic syndrome (Rice-Evans, 1999; Legeay et al., 2015). The presence of the (-)-epigallocatechin gallate in all produced beverages, less $\mathrm{CD}$ and $\mathrm{SH}$, is one of the most important findings of this study.

\section{Sensory properties of the beverages}

The sensorial scoring results are shown in the Figure 5.

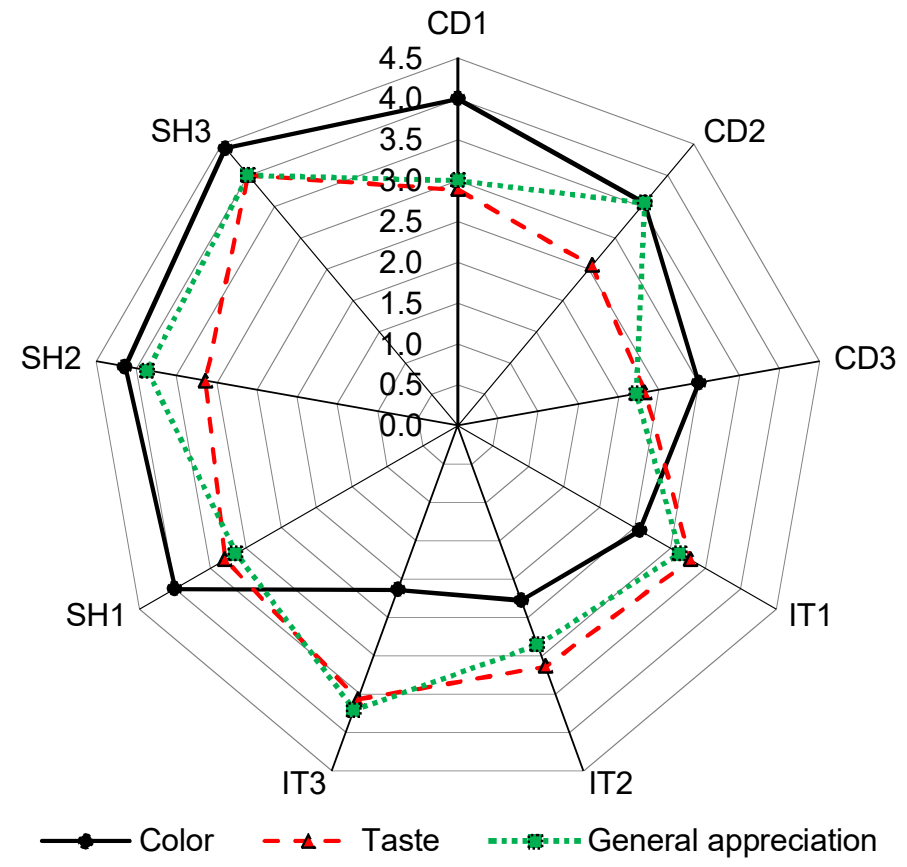

Figure 5. Sensorial scoring test results of the beverages: CD: Carbonated drinks, SH: Sherbets, IT: Iced tea drinks 
Each sample was evaluated within itself beverage group. As CD beverages were evaluated, it is observed that CD1 for color and taste and CD2 for general appreciation had the highest score. In the CD samples, the varying taste balance ratios from 45 to 35 caused to reducing of the sensorial color and taste scores. As similar, the highest color, taste and general appreciation scores were observed in SH3 that had higher taste balance than others among the sherbets. The increasing SGC ratios and carbon dioxide in the $\mathrm{CD}$ were created an unpleasant mouth feeling together. As result, it can be stated the best taste balance ratios in terms of sensorial quality are $40-45$ for $\mathrm{CD}$ and $30-35$ for SH beverages. At the same time, it can be considered being effective of formulation, carbon dioxide using and preservation technique also. In the IT beverage formulations, sour grape concentrate ratios were kept as constant, but sugar contents were changed. The taste and general appreciation scores raised correspondingly, but color scores declined. It is found that the most acceptable taste balance is 35 for sensorial quality in the IT beverage formulation. However, the using of flavour and acidify compounds can cause the changing of that ratio.

\section{Effects of storage on beverages qualities}

The formulated beverages were stored for monitoring of $\mathrm{pH}$, acidity, TP and DPPH inhibitions during six months and the changes were observed in every two months.

The changes of beverage $\mathrm{pH}$ values are shown in Figure 6.

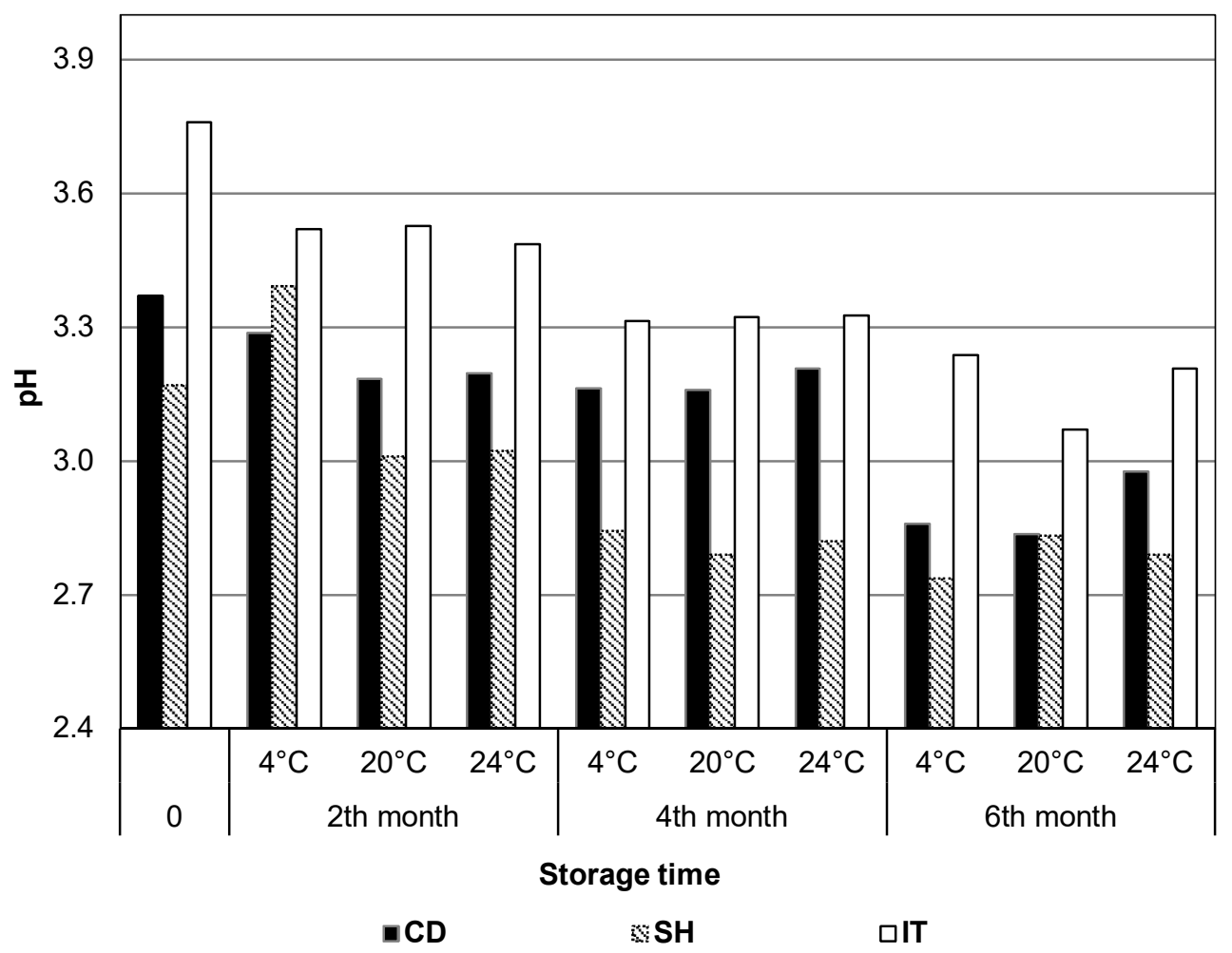

Figure 6. pH changes of the beverages during storage 
The significant statistical differences were observed in the $\mathrm{pH}$ values, and SGC ratio and storage temperature together were important as statistically $(\mathrm{p}<0.05)$. The $\mathrm{pH}$ values decreased by $10.99-11.67 \%$ in $\mathrm{CD}$, by $11.99-15.02 \%$ in $\mathrm{SH}$, and by $12.46-17.17 \%$ in IT beverages to the end of the storage at $24^{\circ} \mathrm{C}$. The decreasing of the $\mathrm{pH}$ values were 9.95 $15.83 \%$ in $\mathrm{CD}, 10.62-13.21 \%$ in $\mathrm{SH}$, and $17.26-18.06 \%$ in IT samples stored at $20^{\circ} \mathrm{C}$, and $11.02-15.03 \%$ in $\mathrm{CD}, 12.50-14.40 \%$ in $\mathrm{SH}$ and $13.26-14.23 \%$ in IT beverages stored at $4^{\circ} \mathrm{C}$. The least $\mathrm{pH}$ values were found in the IT and $\mathrm{SH}$ beverages at $20^{\circ} \mathrm{C}$ and $24^{\circ} \mathrm{C}$ the storage temperatures, respectively. There were the similar results in $\mathrm{CD}$ samples $\mathrm{pH}$ values in except $\mathrm{CD} 3(\mathrm{p}<0.05)$. The highest $\mathrm{pH}$ was observed in $\mathrm{CD} 1$ stored at $24^{\circ} \mathrm{C}$, while the least value was found in $\mathrm{CD} 3$ at $20^{\circ} \mathrm{C}$. In the $\mathrm{SH}$ beverages, the highest and lowest $\mathrm{pH}$ values were measured SH3 and SH1 stored at $4^{\circ} \mathrm{C}$, respectively. In the IT samples, IT2 and IT3 had the highest and lowest $\mathrm{pH}$ values stored at $20^{\circ} \mathrm{C}(\mathrm{p}<0.05)$.

Gonzalez-Molina et al. (2012) reported that $\mathrm{pH}$ and titratable acidity of fruit juice mixture (lemon, elderberry and grape juice concentrate) and control juices over the 56 day of storage no changed as statistically. Balaswamy et al. (2011) found that changes in the $\mathrm{pH}$ were negligible as statistically after 6 months of storage at room temperature in all studied sour grape based ready to serve beverages. On the other hand, Jooyandeh (2015) stated that $\mathrm{pH}$ values of naturally carbonated beverages decreased from 3.2 to 2.9 in red plum beverages and from 3.4 to 3.2 in yellow plum beverages to the end of the 90 days of storage. Moreover, the $\mathrm{pH}$ values of carbonated pineapple juice reduced from 4.10 to 2.98 after 9 weeks storage (Jori et al., 2015). The $\mathrm{pH}$ values in our study were in accordance with these previous reported in literature.

The SGC ratios and storage temperatures effects on TP content in CD beverages were found as statistically significant, but this was no for SH and IT samples $(\mathrm{p}<0.05)$. TP contents were similar at 20 and $24{ }^{\circ} \mathrm{C}$ at the end of the storage, but less of the storage at $4{ }^{\circ} \mathrm{C}$. The TP contents of CD samples decreased between 26 and 32\% comparing to the storage beginning. On the other hand, there were no significant changes of the SH and IT beverages TP contents. Gollücke et al. (2009) studied on TP content of grape juice concentrate during process and storage period. They stated that retention of TP was $90 \%$ and $81 \%$ for Concord and Isabella grape juice during storage, respectively. In the another study, TP content of pomegranate juice decreased from 1858 to $476 \mathrm{mg} / \mathrm{L}$ stored at $4{ }^{\circ} \mathrm{C}$ and $458 \mathrm{mg} / \mathrm{L}$ stored at $20{ }^{\circ} \mathrm{C}$ after 6 months (Tastan et al., 2015).

The changes of DPPH inhibitions during storage can be seen in Figure 7. The inhibitions in SH decreased between 5.2 and $68.9 \%$ according to initial after 6 months storage. The furthest declining in inhibition was observed in $\mathrm{SH}$ beverages that were stored at $24{ }^{\circ} \mathrm{C}$. The inhibitions in ice tea samples decreased $5.5-41.7 \%$ end of the storage. The decreases in IT samples having stored at $20{ }^{\circ} \mathrm{C}$ and $24{ }^{\circ} \mathrm{C}$ was higher than stored at $4{ }^{\circ} \mathrm{C}$.

On the other hand, there were variations in CD samples results in terms of DPPH inhibitions according to SH and IT. The inhibitions increased between 3.9 and $25.11 \%$ in CD samples after 6 months storage. These increases in CD beverages stored at 20 and $24^{\circ} \mathrm{C}$ were higher than stored at $4{ }^{\circ} \mathrm{C}$. 


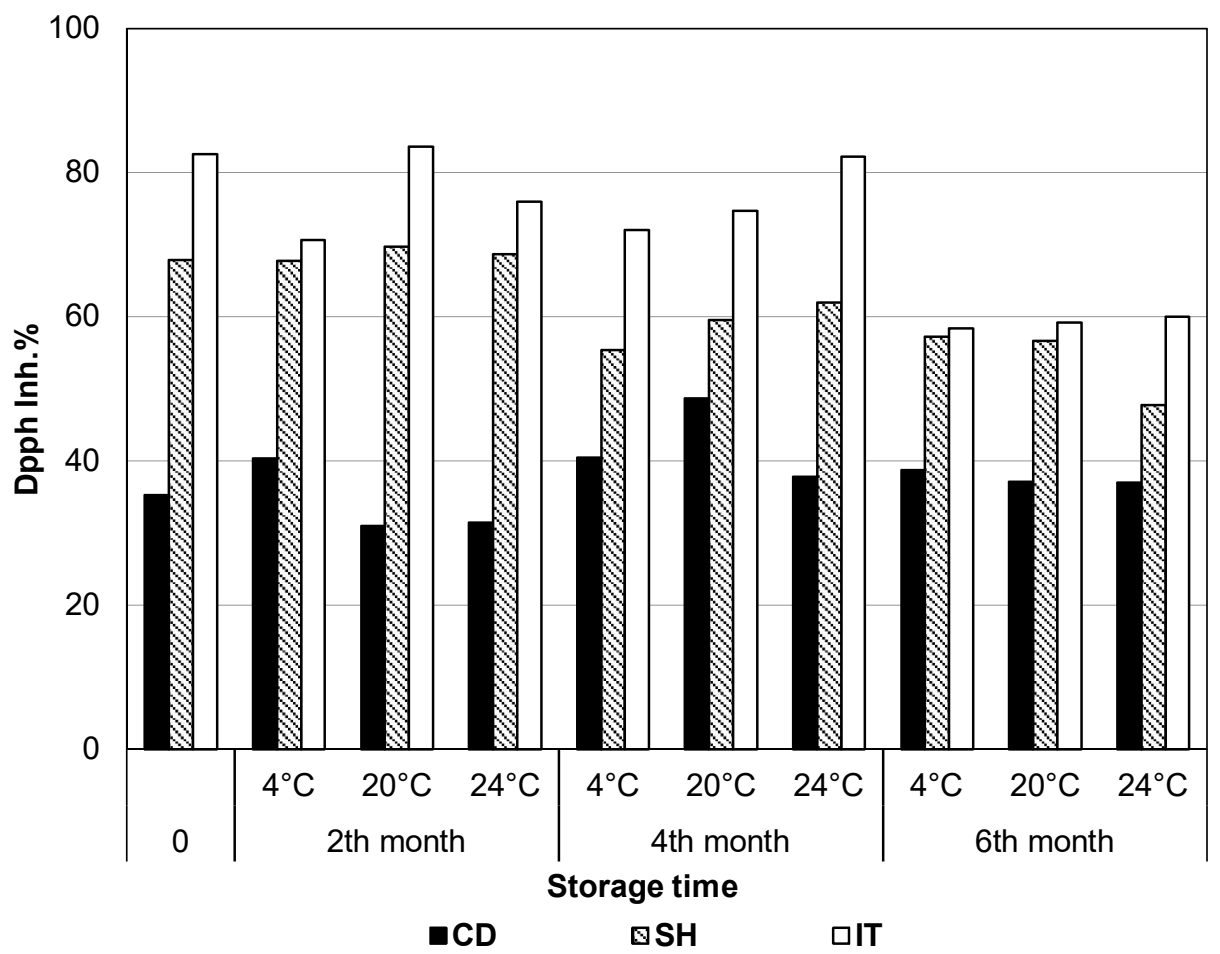

Figure 7. The changes of DPPH inhibitions during storage

\section{Conclusion}

1. This study revealed usability of the sour grape juice in beverages such like carbonated drinks, sherbets and iced teas, and identified their physicochemical properties, color and clarity, mineral and sugar compositions, total phenolic content, antioxidant capacity and individual polyphenols. The sugar-acid balance set between 20 and 45 for beverages by using ingredients. Minerals, total phenolic contents, antioxidant capacities and individual phenolic compounds in the beverages increased depending on used SGC rising ratios. The preferred concentrate ratios and used ingredients changed color and clarity also.

2. In the beverages, $\mathrm{Ca}$ and $\mathrm{Na}$ were the most abundant minerals among major minerals and $\mathrm{Fe}$ in minors. Total phenolic content in the iced tea was approximately in ten fold higher than in carbonated drinks and sherbets. There were also the similar situation in the contents of flavonoids, polyphenol compounds and antioxidant capacities.

3. Gallic acid was the most abundant phenolic acid in the beverages and (-)-epicatechin for IT samples the most abundant flavonols. (-)-Epigallocatechin gallate has higher antioxidant capacity than other catechins and is an important substance for human health. The presence of the (-)-epigallocatechin gallate in all produced beverages, less $\mathrm{CD}$ and $\mathrm{SH}$, is one of the most important findings of this study.

4. The acceptable taste balance values in terms of the sensorial general appreciation were 40-45 for CD, 30-35 for SH and 35 for IT. 
5. The beverages $\mathrm{pH}$, acidity, total phenolic content and DPPH inhibition can be changed based on storage temperatures and duration. At the end of the storage, beverage $\mathrm{pH}$ values slightly decreased and acidities increased. Total phenolic contents were similar at 20 and $24{ }^{\circ} \mathrm{C}$ after storage, but less at $4{ }^{\circ} \mathrm{C}$. In addition, these values decreased between 26 and 32\% comparing to the storage beginning in carbonated drinks.

Acknowledgements. This research is a part of the doctoral thesis of the corresponding author. The author would like to thank for financial support to Manisa Celal Bayar University Scientific Research Projects Coordination Unit and, for guiding and supporting suggestions to thesis advisor Prof. Dr. Ozlem Tokusuglu.

\section{References}

Agca A.C., Batcioglu K., Sarer E. (2020), Evaluation on gallic acid, EGCG contents and antiradical activity of green tea and black tea extracts, J. Fac. Pharm. Ankara / Ankara Ecz. Fak. Derg., 44, pp. 50-60.

Altuğ T., Elmacı Y. (2005), Gidalarda Duyusal Değerlendirme, Meta Basım Matbaacılık, İzmir, Turkey, ISBN 975-97408-1-8.

AOCS. (1999), Recommended Method of Analysis, AOCS, USA.

Apak R., Guclu K., Ozyurek M., Karademir S.E. (2004), Novel total antioxidant capacity index for dietary polyphenols and vitamins $\mathrm{C}$ and $\mathrm{E}$, using their cupric ion reducing capability in the presence of neocuproine: CUPRAC method, J. Agric. Food Chem., 52, pp. 7970-7981.

Artık, N., Poyrazoğlu E.S. (1996), Akbulut, M. Türk elma suyu konsantrelerinin laktik asit düzeyleri üzerine araştırma, The Journal of Food/Glda, 21, pp. 41-48.

Atalay D., Erge H.S. (2017), Determination of some physical and chemical properties of white, green and black teas (Camellia Sinensis), The Journal of Food, Glda., 42, pp. 494-504.

Balaswamy K., Rao P.P., Nagender A., Satyanarayana A. (2011), Preparation of sour grape (vitis vinifera) beverages and evaluation of their storage stability, Food Processing \& Technology, 2, pp. 1-4.

Benzie I.F., Strain J. (1999), Ferric reducing/antioxidant power assay: Direct measure of total antioxidant activity of biological fluids and modified version for simultaneous measurement of total antioxidant power and ascorbic acid concentration, Method. Enzymol., 299, pp. 15-27.

Brand-Williams W., Cuvelier M.E., Berset C. (1995), Use of free radical method to evaluate antioxidant activity, Lebensm. Wiss. Technology., 28, pp. 25-30.

Brenna O.V., Ceppi E.L.M., Giovanelli G. (2009), Antioxidant capacity of some caramelcontaining soft drinks, Food Chem., 115, pp. 119-123.

Cabrera C., Gimenez R., Lopez M.C. (2003), Determination of tea components with antioxidant activity, J. Agric. Food Chem., 51, pp. 4427-4435.

Callaghan C.M., Leggett R.E., Levin R.M. (2013), A comparison of total antioxidant capacities of concord, purple, red, and green grapes using the CUPRAC assay, Antioxidants., 2, pp. 257-264.

Castellari M., Versari A., Spinabelli U., Galassi A., Amati A. (2000), An improved HPLC method for the analysis of organic acids, carbohydrates and alcohols in grape musts and wines, J. Liq. Chromatogr. Relat. Technol., 23, pp. 2047-2056. 
Cook N.C., Samman S. (1996), Flavonoids-chemistry, metabolism, cardioprotective effects, and dietary sources, J. Nutr. Biochem., 7, pp. 66-76.

Fernandez P.L., Pablos F., Martin M.J., Gonzalez A.G. (2002), Study of catechin and xanthine tea profiles as geographical tracers, J. Agric. Food Chem., 50, pp. 1833-1839.

Gollücke A.P.B., Catharino R.R., De Souza J.C., Eberlin M.N., Tavares D.Q. (2009), Evolution of major phenolic components and radical scavenging activity of grape juices through concentration process and storage, Food Chem., 112, pp. 868-873.

Gonzalez-Molina E., Girones-Vilaplana A., Mena P., Moreno D.A., Garcia-Viguera C. (2012), New beverages of lemon juice with elderberry and grape concentrates as a source of bioactive compounds, J. Food Sci., 77, pp. C727-C733.

Granato D., Calado V.M.A., Jarvis B. (2014), Observations on the use of statistical methods in food science and technology, Food Res. Int., 55, pp. 137-149.

Gruenwald J. (2009), Novel botanical ingredients for beverages, Clin. Dermatol., 27, pp. 201-216.

Guimaraes L., Klabjan D., Almada-Lobo B. (2012), Annual production budget in the beverage industry, Eng. Appl. Artif. Intell., 25, pp. 229-241.

Guler A., Candemir A., Merken O., Asıklar F.B., Dilli Y., Yildiz N. (2019), Determination of physical, biochemical and antioxidant properties and mineral compositions of some new developed grape varieties and selected clones from Turkey, Fresenius Environ. Bull., 28, pp. 10146-10153.

Guler A., Tokusoglu O., Artik N. (2018), Alterations on phenolic compounds and antioxidant activity during sour grape juice concentrate processing, Ciência Téc. Vitiv., 33, pp. 136144.

Hayoglu I., Kola O., Kaya C., Özer S., Türkoğlu H. (2009), Chemical and sensory properties of verjuice, a traditional Turkish non-fermented beverage from Kabarcık and Yediveren grapes, J. Food. Process. Pres., 33, pp. 252-263.

Jooyandeh H. (2015), Manufacturing of a novel naturally carbonated fruit beverage, J. Appl. Environ. Biol. Sci., 4, pp. 47-53.

Jori D., Ladole M., Gore A., Bhand V. (2013), Study on effect of carbonation on storage and stability of pineapple fruit juice, Int. J. Eng. Res. Technol., 2, pp. 1841-1847.

Legeay S., Rodier M., Fillon L., Faure S., Clere, N. (2015), Epigallocatechin gallate: A review of its beneficial properties to prevent metabolic syndrome, Nutrients., 7, pp. $5443-5468$.

Lugasi A., Hovari J. (2003), Antioxidant properties of commercial alcoholic and nonalcoholic beverages, Nahrung/Food, 47(7), pp. 9-86.

Makris D.P., Boskou G., Andrikopoulos N.K., Kefalas P. (2008), Characterisation of certain major polyphenolic antioxidants in grape (Vitis vinifera cv. Roditis) stems by liquid chromatography-mass spectrometry, Eur. Food Res. Technol., 226, pp. 1075-1079.

Martinez-Flores H.E., Garnica-Romo G., Bermudez-Aguirre D., Pokhrel P.R., BarbosaCanovas G.V. (2015), Physico-chemical parameters, bioactive compounds and microbial quality of thermo-sonicated carrot juice during storage, Food Chem., 172, pp. 650-656.

Nanasombat S., Thonglong J., Jitlakha J. (2015), Formulation and characterization of novel functional beverages with antioxidant and anti-acetylcholinesterase activities, Funct. Food Health Dis., 5, pp. 1-16

Natividade M.M.P., Correa L.C., Souza S.V.C., Pereira G.E., Lima, L.C.O. (2013), Simultaneous analysis of 25 phenolic compounds in grape juice for HPLC: Method validation and characterization of São Francisco Valley samples, Microchem. J., 110, pp. 665-674. 
Nikfardjam M.S.P. (2008), General and polyphenolic composition of unripe grape juice (verjus/verjuice) from various producers, Mitt. Klosterneuburg., 58, pp. 28-31.

Öncül N., Karabıyıklı Ş. (2015), Factors affecting the quality attributes of unripe grape functional food products, J. Food Biochem., 39, pp. 689-695.

Ough C.S., Amerine M.A. (1998), Methods for Analysis of Must and Wines, John Wiley and Sons, New York.

Pastrana-Bonilla E., Akoh C.C., Sellappan S., Krewer G. (2003), Phenolic content and antioxidant capacity of muscadine grapes. J. Agric. Food Chem., 51, pp. 5497-503.

Pekal A., Drozdz P., Biesaga M., Pyrzynska K. (2011), Evaluation of the antioxidant properties of fruit and flavoured black teas, Eur. J. Nutr., 50, 6pp. 81-688.

Piva A., Di Mattia C., Neri L., Dimitri G., Chiarini M., Sacchetti G. (2008), Heat-induced chemical, physical and functional changes during grape must cooking, Food Chem., 106, pp. 1057-1065.

Porgalı E., Büyüktuncel E. (2012), Determination of phenolic composition and antioxidant capacity of native red wines by high performance liquid chromatography and spectrophotometric methods, Food Res. Int., 45, pp. 145-154.

Re R., Pellegrini N., Proteggente A., Pannala A., Yang M., Rice-Evans C. (1999), Antioxidant activity applying an improved ABTS radical cation decolorization assay, Free Radic. Biol. Med., 26, pp. 1231-1237.

Rice-Evans C. (1999), Implications of the mechanisms of action of tea polyphenols as antioxidants in vitro for chemoprevention in humans, Proc. Soc. Exp. Biol. Med., 220, pp. 262-266.

Rosa M., Prado C., Podazza G., Interdonato R., González J.A., Hilal M., Prado F.E. (2009), Soluble sugars: Metabolism, sensing and abiotic stress: A complex network in the life of plants, Plant Signal. Behav., 4, pp. 388-393.

Sabir A., Kafkas E., Tangolar S. (2010), Distribution of major sugars, acids and total phenols in juice of five grapevine (Vitis spp.) cultivars at different stages of berry development, Span. J. Agric. Res., 8, pp. 425-433.

Silva E.d.S., da Silva E.G.P., Silva D.d.S., Novaes C.G., Amorim F.A.C., Santos M.J.S.d., Bezerra M.A. (2019), Evaluation of macro and micronutrient elements content from soft drinks using principal component analysis and Kohonen self-organizing maps, Food Chem., 273, pp. 9-14.

Singleton V.L., Rossi J.A. (1965), Colorimetry of total phenolics with phosphomolybdicphosphotungstic acid reagents, Am. J. Enol. Viticult., 16, pp. 144158.

Singleton V.L., Timberlake C.F., Lea A.G.H. (1978), The phenolic cinnamates of white grapes wine, J. Sci. Food Agric., 27, pp. 403.

Tastan O., Baysal T. (2015), Clarification of pomegranate juice with chitosan: Changes on quality characteristics during storage, Food Chem., 180, pp. 211-218.

Turkmen F.U., Takci H.A., Sekeroglu N. (2017), Total phenolic and flavonoid contents, antioxidant and antimicrobial activities of traditional unripe grape products, Indian $J$. Pharm. Educ., 51, pp. 489-493.

Verma S., Gupta S., Sharma B. (2014), Utilisation of aonla and lime for development of fruit based carbonated soft drinks, Int. J. Pharm. Sci. Res., 4, pp. 155-162.

Wern K.H., Haron H., Keng C.B. (2016), Comparison of total phenolic contents (TPC) and antioxidant activities of fresh fruit juices, commercial 100\% fruit juices and fruit drinks, Sains Malays., 45, pp. 1319-1327. 
WHO (2021). Potassium intake for adults and children, available at: https://www.who.int/nutrition/publications/guidelines/potassium_intake_printversion. pdf (accessed on 1 February 2021)

Wu J.J., Chiang M.T., Chang Y.W., Chen J.Y., Yang H.T., Lii C.K., Lin J.H., Yao H.T. (2011), Correlation of major components and radical scavenging activity of commercial tea drinks in Taiwan, J. Food Drug Anal., 19, pp. 289-300.

Xia E.Q., Deng G.F., Guo Y.J., Li H.B. (2010), Biological activities of polyphenols from grapes, Int. J. Mol. Sci., 11, pp. 622-646.

Yang J., Martinson T.E., Liu R.H. (2009), Phytochemical profiles and antioxidant activities of wine grapes, Food Chem., 116, pp. 332-339.

Zaitoun M., Ghanem M., Harphoush S. (2018), Sugars: Types and Their Functional Properties in Food and Human Health, Int. J. Public Health Res., 6, pp. 93-99.

Zuo Y., Chen H., Deng Y. (2002), Simultaneous determination of catechins, caffeine and gallic acids in green, Oolong, black and pu-erh teas using HPLC with a photodiode array detector, Talanta., 57, pp. 307-316. 